\title{
THE DEVELOPMENT OF OPTICAL SENSOR FOR INORGANIC SALTS DETECTION IN WATER
}

\author{
${ }^{1}$ Polina BAINOVA, ${ }^{1,2}$ Elena MILIUTINA, ${ }^{1}$ Vaclav ŠVORČíK, ${ }^{1,2}$ Pavel POSTNIKOV, \\ 1,2Oleksiy LYUTAKOV \\ ${ }^{1}$ VŠCHT - University of Chemistry and Technology, Prague, Czech Republic, EU, Iyutakoo@vscht.cz \\ ${ }^{2}$ Tomsk Polytechnic University, Research School of Chemistry and Applied Biomedical Sciences, Tomsk, \\ Russian Federation
}

https://doi.org/10.37904/nanocon.2020.3711

\begin{abstract}
The main goal of this work is to create a highly sensitive optical sensor based on the principle of plasmon surface resonance (SPR) for inorganic salts. The experimental concept includes the creation of optical fiber probe with anion capturing agent(ACA) through the diazonium chemistry for selective-entrapping of targeted compounds and their trace amounts detection. The characterization of the obtained structures and their properties were performed using the SERS, AFM and UV-Vis methods. The created hybrid sensor structures were used to measure the presence and concentration of inorganic salts, which often occur in polluted wastewater. The proposed approach has a number of advantages, such as the possibility of real-time detection, high selectivity and sensitivity, and the possibility of miniaturization of the analytical device(s).
\end{abstract}

Keywords: Fiber optic, sensor, detection, anions, pollution, capturing agents

\section{INTRODUCTION}

Today, industrial production and agriculture development led to increasing release of inorganic anions in our environment. Released anions formed from toxic organic and inorganic waste products represents a serious ecological risk. [1,2]. These compounds show potential toxic effects even at relatively low concentrations [3,4]. E.g. nitrate anion $\left(\mathrm{NO}_{3}^{-}\right)$or phosphate compounds $\left(\mathrm{eg}_{2} \mathrm{PO}_{4}^{-}\right)$from agricultural wastewater can lead to eutrophication of watercourses [5-7]. Nitrate and nitrite anions $\left(\mathrm{NO}_{2}^{-}\right)$can cause methemoglobinemia in animals or humans organisms $[8,9]$. Sulphate $\left(\mathrm{SO}_{4}{ }^{2-}\right)$ and bisulphate $\left(\mathrm{HSO}_{4}{ }^{-}\right)$anions are commonly present in radioactive waste and induce a number of problems during water storage and recycling $[10,11]$. Therefore, it is necessary to control and regulate the concentration of anions in various areas, such as public water mains, river water, various types of drinking water and industrial wastewater.

Effective on-site monitoring of anions requires methods that allow the determination of their low concentrations in the aqueous environment. However, anionic analysis equipment (such as ion chromatography) is very expensive, requires the transport of samples to the laboratory, and the analysis itself takes a lot of time. Recently, fluorescent anionic chemosensors have been developed for this task $[12,13]$. Other methods of optical detection are also being studied, including the use of chromogenic sensors [14]. However, these methods also have several disadvantages: they require preliminary sample preparation, the production of such sensors is laborious and relatively expensive. The solution to these problems is to become fiber-optic sensors with ligand groups on the surface, selective to anions. Today, fiber optic sensors are an efficient, accurate and cheap tool for the determination of various analytes [15-17].

In this work, we propose an optical approach to the detection of anions. The proposed approach have a number of advantages, such as the possibility of real-time detection, high selectivity and sensitivity, and the possibility of miniaturization of the device. In other words, the main goal of this work is to create a highly sensitive optical 
sensor based on the principle of plasmon surface resonance (SPR), including a anion-selective layer based on ACA modification for the detection of trace amounts of anions in water in real time. Particular attention will be paid to anions, which often occur in polluted wastewater: $\mathrm{NO}_{3}{ }^{-}, \mathrm{H}_{2} \mathrm{PO}_{4}^{-}, \mathrm{NO}_{2}{ }^{-}, \mathrm{SO}_{4}{ }^{2-}$.

\section{EXPERIMENTAL}

\subsection{Materials}

Gold targets for metal deposition (purity of metals, $4 \mathrm{~N}$ ) were purchased from Safina. Multimode plastic-clad silica optical (PCS) fiber was purchased from CeramOptec (Germany) with core and buffer/cladding diameters of 200 and 230/500 $\mu \mathrm{m}$, respectively. Deionized water, methanol (reagent grade, $\geq 99,8 \%$ ), acetone (97\%), zinc nitrate hexahydrate $(\geq 99.0 \%)$, sodium dihydrogen phosphate $(\geq 99.0 \%)$, sodium nitrite $(\geq 97.0 \%)$, sodium sulfate $(\geq 99.0 \%)$, were purchased from Sigma-Aldrich and used without further purification.

\subsection{Sample preparation.}

Preparation of fiber-optical sensor.

The $2 \mathrm{~cm}$ of PCS fiber shell was thermally removed, and naked PCS core was purified using washing with deionized water, acetone and methanol. A thin film of Au was deposited on the PCS fiber core by vacuum sputtering (thickness approx. $40 \mathrm{~nm}$ ). The deposition of Au was accomplished from Au target (DC Ar plasma, gas purity - $99.995 \%$, pressure $4 \mathrm{~Pa}$, discharge power $7.5 \mathrm{~W}$, sputtering time $400 \mathrm{sec}$ ). The fibers were fixed with the replaceable SMA connectors.

\section{Sensor modification.}

The obtained optical fibers with gold were electrochemistry modified ( $4 \mathrm{mM}$ freshly prepared water solutions, $-3.0 \mathrm{~V}$ applied potential) for $2 \mathrm{~min}$. After modification, fibers were rinsed with water, methanol, and acetone for $20 \mathrm{~min}$, and dried at ambient conditions.

\subsection{Measurement Techniques}

Raman spectra were measured using ProRaman-L spectrometer (Laser power $40 \mathrm{~mW}$ ) with $785 \mathrm{~nm}$ excitation wavelengths. Spectra were measured 30 times, each of them with $3 \mathrm{~s}$ accumulation time.

UV-Vis absorbance spectra of the samples were measured using a HR2000 (Ocean Optics) spectrometer in 400-800 nm wavelengths range using the AvaLight-DHS light source (Avantes). ACA-coated Au fibers were immersed in water solutions of $\mathrm{NaNO}_{2}, \mathrm{Na}_{2} \mathrm{SO}_{4}, \mathrm{NaH}_{2} \mathrm{PO}_{4}$ and $\mathrm{Zn}\left(\mathrm{NO}_{3}\right)_{2}$ in different concentrations $10^{-6}, 10^{-4}$, $10^{-2}$ and $1 \mathrm{M}$.

\section{RESULTS AND DISCUSSION}

The experimental concept is presented in Figure 1. An optical fiber covered with an thin layer of Au film was modified with ACA. (Step A) In the next step, the optical fiber was coupled to a light source and with spectrometer. When the sensor is immersed in water, the surface plasmon resonance effect appears on the surface, and an absorption peak as well visible. The position of absorption peak depends on the refractive index of surrounding medium (Step B). Immersion of a modified sensor in an analyte solution leads to pronounced shift of SPR wavelength position, indicating the capture of anions on surface of the sensor. (Step C) The following salts: $\mathrm{NaNO}_{2}, \mathrm{Na}_{2} \mathrm{SO}_{4}, \mathrm{NaH}_{2} \mathrm{PO}_{4}$ and $\mathrm{Zn}\left(\mathrm{NO}_{3}\right)_{2}$ were used as analyte solutions.

The modification of the sensor surface was confirmed by Raman spectroscopy (Figure 2). The results of Raman spectroscopy show the appearance of characteristic vibration bands of aromatics and $-\mathrm{CH}_{3}$ after modification. 


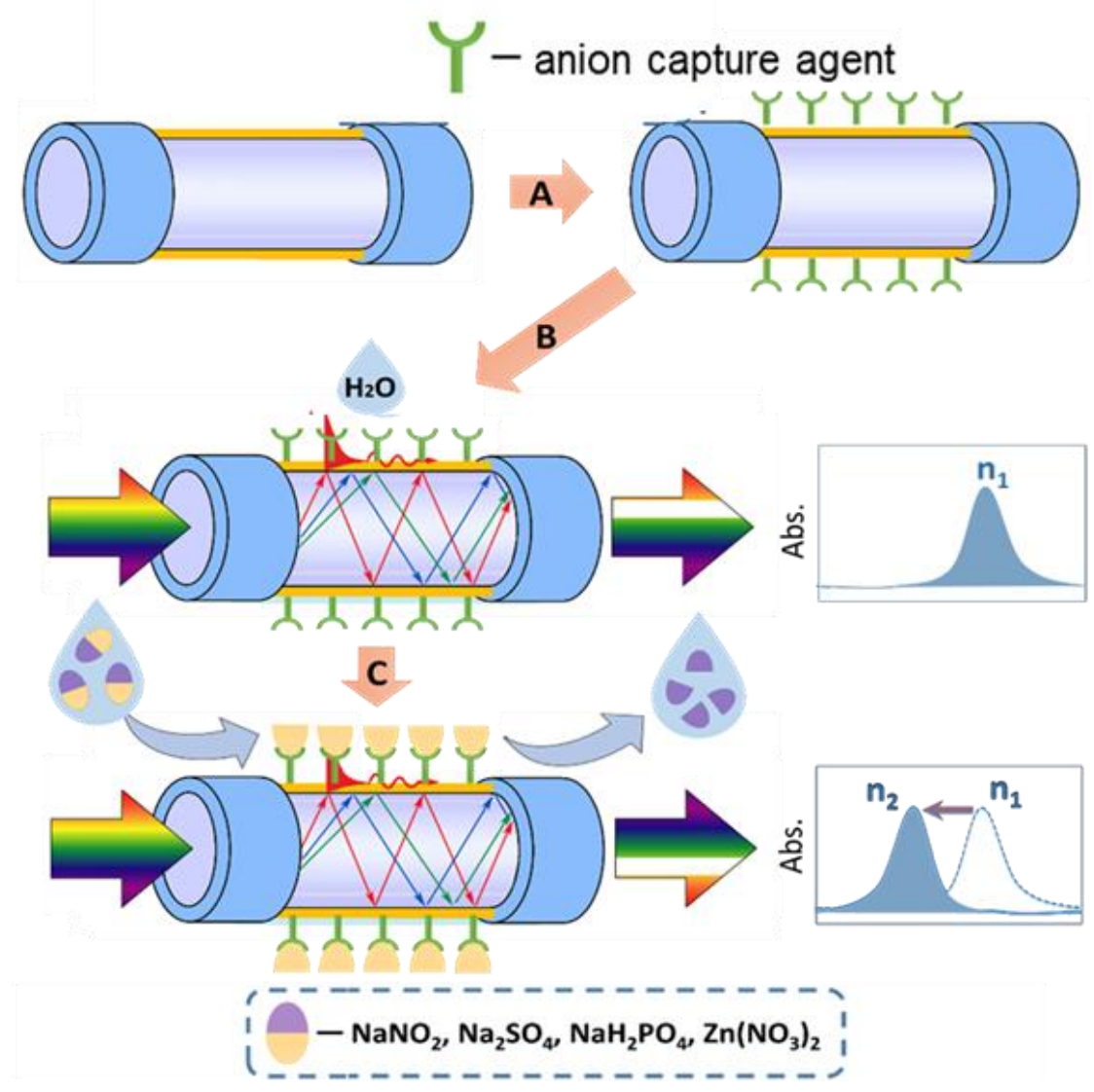

Figure 1 Scheme of preparation and use of an optical sensor. A - pre-modification of the sensor in a freshly prepared aqueous solution of the ACA, B - immersion of the sensor in the aquatic environment and the occurrence of a plasmon absorption band, $\mathrm{C}$ - capture of anions and subsequent shift of the absorption band.

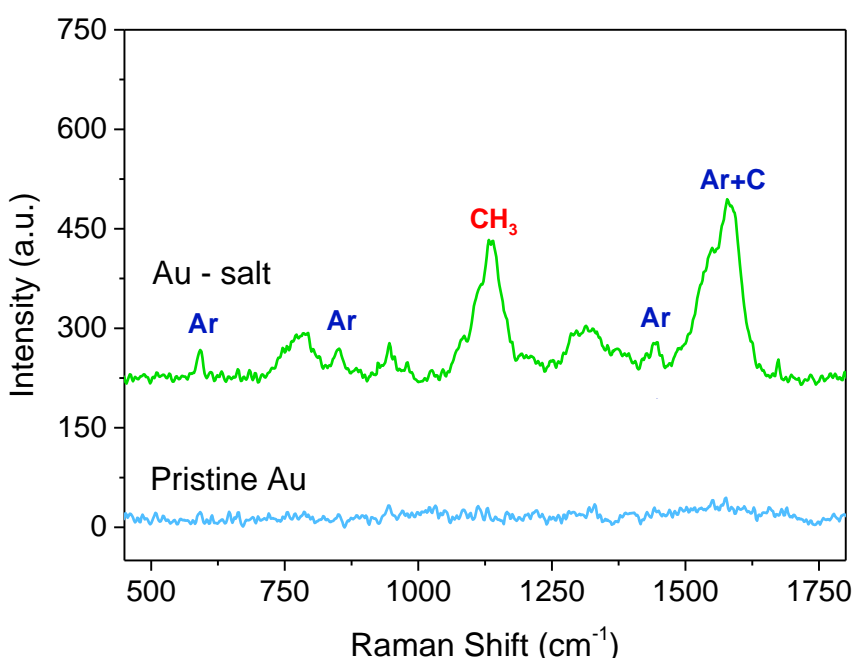

Figure 2 Raman spectra on the surface of: (i) pristine $\mathrm{Au}$, (ii) $\mathrm{Au}$ with ACA

During the experiment, the prepared sensors were immersed in solutions of four different anions with different concentrations, which led to a change in the refractive index of the medium surrounding the plasmon-active part of the sensors. The complete sets of absorption spectra are shown in Figure 3. As can be seen, entrapping of anions effectively affects the position of the absorption maximum of plasmons. 

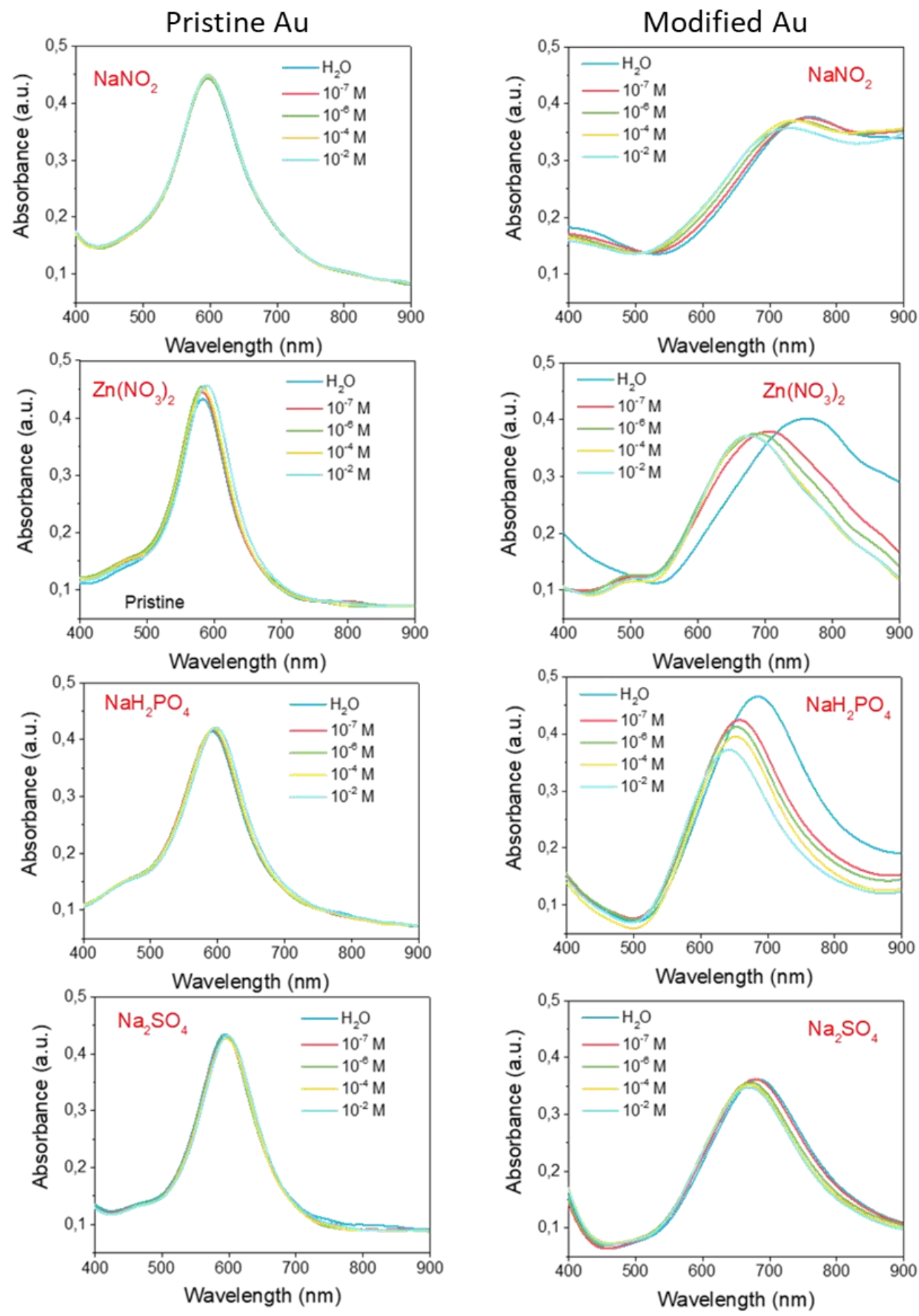

Figure 3 Results of the interaction of pristine and modified sensor with analyte solutions

\section{CONCLUSION}

In this work, fiber-optic sensors were developed for monitoring of anions and determining their concentrations. Our basic concept uses the functionalization of a plasmon-supported fiber surface modified with an ACA. The salt's layer ensures the extraction of anions from model solutions, which causes a shift in the position of the absorption band. The created system demonstrates high sensitivity to nitrite $\left(\mathrm{NO}_{2}{ }^{-}\right)$, nitrate $\left(\mathrm{NO}_{3}{ }^{-}\right)$, dihydrogen phosphate $\left(\mathrm{eg} \mathrm{H}_{2} \mathrm{PO}_{4}{ }^{-}\right)$and sulphate $\left(\mathrm{SO}_{4}{ }^{2-}\right)$ anions. It was found that the lower detectable concentration is 
only $10^{-7} \mathrm{M}$, which makes the proposed sensors comparable to the conventional analytical approach to the determination of water pollution.

\section{ACKNOWLEDGEMENTS}

This work was supported by under the project Internal Grant Agency UCT № 126882005.

\section{REFERENCES}

[1] BUSSCHAERT, N., CALTAGIRONE, C., W. VAN ROSSOM, W., GALE, P. Applications of Supramolecular Anion Recognition. Chem. Rev. 2015, vol. 115, pp. 8038-8155.

[2] OKESOLA, B., SMITH, D. Applying low-molecular weight supramolecular gelators in an environmental setting self-assembled gels as smart materials for pollutant removal. Chem. Soc. Rev. 2016, vol. 45, pp. 4226-4251.

[3] HAI, F., YAMAMOTO, K., FUKUSHI, K. Hybrid Treatment Systems for Dye Wastewater. Crit. Rev. Environ. Sci. Technol. 2007, vol. 37, pp. 315-377.

[4] KIM, H., WATTHANAPHANIT, A., SAITO, N. Simple Solution Plasma Synthesis of Hierarchical Nanoporous MnO2 for Organic Dye Removal. ACS Sustainable Chem. Eng. 2017, vol. 5, pp. 5842-5851.

[5] LIU, G., YOU, S., MA, M., HUANG, H., REN, N. Removal of Nitrate by Photocatalytic Denitrification Using Nonlinear Optical Material. Environ. Sci. Technol. 2016, vol. 50, pp. 11218-11225.

[6] WANG, X., LÜ, S., GAO, C., FENG, C., XU, X., BAI, X., GAO, N., YANG, J., LIU, M., WU, L. Recovery of Ammonium and Phosphate from Wastewater by Wheat Straw-based Amphoteric Adsorbent and Reusing as a Multifunctional Slow-Release Compound Fertilizer. ACS Sustainable Chem. Eng. 2016, vol. 4, pp. 2068-2079.

[7] JI, X., WU, R., LONG, L., GUO, C., KHASHAB, N., HUANG, F., SESSLER, J. Physical Removal of Anions from Aqueous Media by Means of a Macrocycle-Containing Polymeric Network. J. Am. Chem. Soc. 2018, vol. 140, no. 8, pp. 2777-2780.

[8] JIAO, S., JIN, J., WANG, L. One-pot preparation of Au-RGO/PDDA nanocomposites and their application for nitrite sensing. Sens. Actuators B. 2015, vol. 208, pp. 36-42.

[9] ZHANG, Y., SU, Z., LI, B., ZHANG, L., FAN, D., MA, H. Recyclable Magnetic Mesoporous Nanocomposite with Improved Sensing Performance toward Nitrite. ACS Appl. Mater. Interfaces. 2016, vol. 8, pp. 12344-12351.

[10] KIM, S., LEE, J., WILLIAMS, N., LYNCH, V., HAY, B., MOYER, B., SESSLER, J. Bipyrrole-Strapped Calix[4]pyrroles: Strong Anion Receptors That Extract the Sulfate Anion. Am. Chem. Soc. 2014, vol. 136, pp. 15079-15085.

[11] KWON, H., JIANG, W., KOOL, E. Pattern-Based Detection of Anion Pollutants in Water with DNA Polyfluorophores. Chemical Science. 2015, vol. 6, no. 4, pp. 2575-2583.

[12] TAN, S., KIM, Su J., KOOL, E. Differentiating between fluorescence-quenching metal ions with polyfluorophore sensors built on a DNA backbone. J. Am. Chem. Soc. 2011, vol. 133, pp. 2664-2671.

[13] YUEN, L., FRANZINI, R., WANG, S., CRISALLI, P., SINGH, V., JIANG, W., KOOL, E. Pattern-Based Detection of Toxic Metals in Surface Water with DNA Polyfluorophores. Angew. Chem., Int. Ed. 2014, vol. 53, pp. 5361-5365.

[14] KOO, C., WANG, S., GAUR, R., SAMAIN, F., BANAEIB, N., KOOL, E. Fluorescent DNA chemosensors: identification of bacterial species by their volatile metabolites. Chem. Commun. 2011, vol. 47, pp. 11435-11437.

[15] MILIUTINA, E., GUSELNIKOVA, O., CHUFISTOVA, S., KOLSKA, Z., ELASNIKOV, R., BURTSEV, V., POSTNIKOV, P., ŠVORČíK, V., LYUTAKOV, O. Fast and All-Optical Hydrogen Sensor Based on Gold-Coated Optical Fiber Functionalized with Metal-Organic Framework Layer. ACS Sens. 2019, vol. 4, no. 12, pp. 31333140.

[16] MILIUTINA, E., GUSELNIKOVA, O., BURTSEV, V., ELASNIKOV, R., POSTNIKOV, P., ŠVORČíK, V., LYUTAKOV, O. Plasmon-active optical fiber functionalized by metal organic framework for pesticide detection. Talanta. 2020, vol. 208, Article no. 120480.

[17] Miliutina, E., GuSelnikova, O., Kushnarenko, A., Bainova, P., POStNikov, P., hNATOWiCZ, V., SVORCIK, V., LYUTAKOV, O. Single Plasmon-Active Optical Fiber Probe for Instantaneous Chiral Detection. ACS Sens. 2020, vol. 5, no. 1, pp. 50-56. 